\title{
Towards Implantable Bio-Supercapacitors: Pseudocapacitance of Ruthenium Oxide Nanoparticles and Nanosheets in Acids, Buffered Solutions, and Bioelectrolytes
}

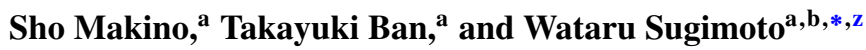 \\ ${ }^{a}$ Materials and Chemical Engineering, Faculty of Textile Science and Technology, Shinshu University, \\ Ueda, Nagano 386-8567, Japan \\ ${ }^{b}$ Center for Energy and Environmental Science, Interdisciplinary Cluster for Cutting Edge Research, \\ Shinshu University, Ueda, Nagano 386-8567, Japan
}

\begin{abstract}
Metal oxides, in particular ruthenium-based oxides, are promising electrode materials for aqueous pseudocapacitors. Strong acids or bases are favored over neutral electrolytes owing to the higher capacitance. Here we explore the pseudocapacitive behavior of ruthenium oxide nanoparticles and nanosheets in near neutral $\mathrm{pH}$ as an environmentally benign electrolyte. The pseudocapacitive charge storage in poorly-crystalline hydrous $\mathrm{RuO}_{2}$ nanoparticles, and highly-crystalline $\mathrm{RuO}_{2}$ nanosheets were investigated in acetic acid-lithium acetate (AcOH-AcOLi) buffered solutions. It is shown that capacitance values as high as $1,038 \mathrm{~F} \mathrm{~g}^{-1}$ can be achieved in AcOH-AcOLi buffered solutions with $\mathrm{RuO}_{2}$ nanosheets, which is $44 \%$ higher than the benchmark $\mathrm{RuO}_{2} \cdot n \mathrm{H}_{2} \mathrm{O}$ in $\mathrm{H}_{2} \mathrm{SO}_{4}$ electrolyte $\left(720 \mathrm{~F} \mathrm{~g}^{-1}\right)$. Furthermore, comparable performance was obtained in phosphate buffered saline and fetal bovine serum. The mechanism of the pseudocapacitive properties is discussed based on the difference in the surface redox behavior of different $\mathrm{RuO}_{2}$ nanomaterials in acid, neutral, buffered solutions, and in weak acid.

(C) The Author(s) 2015. Published by ECS. This is an open access article distributed under the terms of the Creative Commons Attribution 4.0 License (CC BY, http://creativecommons.org/licenses/by/4.0/), which permits unrestricted reuse of the work in any medium, provided the original work is properly cited. [DOI: 10.1149/2.0021505jes] All rights reserved.
\end{abstract}

Manuscript submitted December 2, 2014; revised manuscript received December 26, 2014. Published January 9, 2015. This paper is part of the JES Focus Issue on Electrochemical Capacitors: Fundamentals to Applications.

Electrochemical capacitors (also known as supercapacitors) are energy harvesting devices capable of charge and discharging within a few seconds, and cycle life in the order of thousands of cycles. Some metal-oxides are known to provide high capacitance in aqueous electrolytes, owing to the combination of the non-faradaic electrical double layer charging and the faradaic surface or near surface confined redox capacitance (psuedocapacitance). ${ }^{1}$ Pseudocapacitance is a phenomenon generally observed in aqueous electrolytes. ${ }^{2}$ Acidic or basic electrolytes such as $\mathrm{H}_{2} \mathrm{SO}_{4}$ and $\mathrm{KOH}$ are favorable in terms of power density owing to the high conductivity. $\mathrm{RuO}_{2}$ is one of the rare oxides that is stable in both acidic and basic conditions. Hydrous $\mathrm{RuO}_{2}$ nanoparticles $\left(\mathrm{RuO}_{2} \cdot n \mathrm{H}_{2} \mathrm{O}\right.$; where $n$ is typically 0.5$)$ offers capacitance of $\sim 700 \mathrm{~F} \mathrm{~g}^{-1}$ in $\mathrm{H}_{2} \mathrm{SO}_{4}$ electrolyte and can be cycled for thousands of cycles with practically no decay, thus is often used for performance benchmarking of new electrode materials. Although studies on the asymmetric systems and applicability of non-aqueous electrolytes to oxide electrodes in order to widen the operating voltage window have recently been initiated, non-aqueous electrolytes have yet to surpass aqueous electrolytes in terms of specific capacitance..$^{3-8}$

Electrolytes near neutral $\mathrm{pH}$ are selected for materials that are not as corrosion-resistant in acids and base, for example manganese oxide. $^{9-12}$ Neutral electrolytes are more environmentally benign and its low corrosiveness allows a wider range in choice for periphery material, such as current collectors and packaging. ${ }^{13}$ Despite the $\mathrm{RuO}_{2}$ based material being the model pseudocapacitive material, studies on the electrochemical capacitor behavior in neutral electrolytes are scarce compared to the more popular acidic or basic electrolytes. One of the reasons is that the capacitance of $\mathrm{RuO}_{2}$ in neutral electrolytes is generally $1 / 2$ of that in sulfuric acid or potassium hydroxide. ${ }^{14-17}$ Nonetheless, the use of neutral $\mathrm{pH}$ electrolytes has advantages when used for asymmetric (hybrid) supercapacitors, which are devices that utilize different materials (e.g. metal oxides, carbon, etc) for the positive and negative electrodes. ${ }^{12}$ In such a case, the operating voltage window can be extended beyond the thermodynamic $1.2 \mathrm{~V}$ limit if the kinetics of gas evolution is extremely slow. Up to now, alkali metal sulfates, nitrates, and chlorides have been used as neutral electrolytes.

*Electrochemical Society Active Member.

${ }^{\text {z} E-m a i l: ~ w s u g i @ s h i n s h u-u . a c . j p ~}$
We have also used $\mathrm{Li}_{2} \mathrm{SO}_{4}$ as the electrolyte for our hybrid supercapacitors based on protected $\mathrm{Li}$ anode technology. ${ }^{18-20}$ This hybrid supercapacitor utilizes a $\mathrm{Li}$ ion conducting glass ceramic membrane, which is stable within a limited $\mathrm{pH}$ range. We recently communicated that unprecedented capacitance values exceeding that of $\mathrm{H}_{2} \mathrm{SO}_{4}$ can be achieved by using an acetic acid-lithium acetate (AcOH-AcOLi) buffered solution with near neutral $\mathrm{pH},{ }^{20}$ suggesting the possibility of other new electrolytes.

In this study, emphasis was placed on elucidating the origin and mechanism of the pseudocapacitance of ruthenium based oxides in buffered solutions. Three different nanostructured $\mathrm{RuO}_{2}$ materials were studied; namely poorly crystalline hydrous $\mathrm{RuO}_{2}$ nanoparticles, well-crystalline anhydrous $\mathrm{RuO}_{2}$ nanoparticles, and crystalline $\mathrm{RuO}_{2}$ nanosheets. The capacitive behavior of these materials were studied in $\mathrm{H}_{2} \mathrm{SO}_{4}$ as the acidic electrolyte, or $\mathrm{Li}_{2} \mathrm{SO}_{4}$ or AcOLi as neutral electrolyte. Various AcOH-AcOLi buffer solutions with different ionic strength (constant $\mathrm{pH}$ ) were used, and the ratio of weak acid/conjugated base ratio was also varied. In addition, the role of weak acid was investigated by adding a small amount of $\mathrm{AcOH}$ to a supporting electrolyte $\left(\mathrm{Li}_{2} \mathrm{SO}_{4}\right)$. Furthermore, phosphate buffered saline and fetal bovine serum were studied as bioelectrolytes for application toward implantable bio-supercapacitors.

\section{Experimental}

Ultrapure water (Milli-Q, $>18 \mathrm{M} \Omega \mathrm{cm}$ ) was used for all synthesis and characterization. $\mathrm{RuO}_{2} \cdot n \mathrm{H}_{2} \mathrm{O}$ was prepared by a modified solgel process following literature. ${ }^{21,22} \mathrm{In}$ a typical synthesis, a $0.3 \mathrm{M}$ $\mathrm{NaOH}$ solution was slowly added to a $0.1 \mathrm{M}$ aqueous $\mathrm{RuCl}_{3}$ solution while maintaining a constant $\mathrm{pH}$ value of 7 . The precipitate was collected and washed thoroughly to remove by-products. The product was suspended in $\mathrm{H}_{2} \mathrm{O}$ and aged for $72 \mathrm{~h}$ at $40^{\circ} \mathrm{C}$. The powder samples were collected and heat treated in air at $150^{\circ} \mathrm{C}$ for $17 \mathrm{~h}$ to obtain $\mathrm{RuO}_{2} \cdot n \mathrm{H}_{2} \mathrm{O}(n=0.5)$. Anhydrous $\mathrm{RuO}_{2}$ was prepared by calcination of $\mathrm{RuO}_{2} \cdot x \mathrm{H}_{2} \mathrm{O}$ (Johnson Matthey) at $450^{\circ} \mathrm{C}$ for $2 \mathrm{~h}$.

Ruthenium oxide nanosheets $\left(\mathrm{RuO}_{2} \mathrm{~ns}\right)$ were synthesized following a previously reported method. ${ }^{23}$ Briefly, $\alpha-\mathrm{NaFeO}_{2}$ type $\mathrm{NaRuO}_{2}$ was synthesized by solid state reaction of $\mathrm{Na}_{2} \mathrm{CO}_{3}, \mathrm{Ru}$ and $\mathrm{RuO}_{2}$ (2: 1: 3 molar ratio) at $900^{\circ} \mathrm{C}$ for $12 \mathrm{~h}$ under $\mathrm{Ar}$ atmosphere. Oxidative 
Table I. List of buffered solutions used.

\begin{tabular}{cccc} 
Electrolyte & $\begin{array}{c}\text { Mixing } \\
\text { volume ratio }\end{array}$ & $\mathrm{pH}$ & $\begin{array}{c}\text { Conductivity/ } \\
\mathrm{S} \mathrm{m}^{-1}\end{array}$ \\
\hline $0.5 \mathrm{M} \mathrm{AcOH}-\mathrm{AcOLi}$ & $12.5: 87.5$ & 5.4 & 2.15 \\
$2.0 \mathrm{M} \mathrm{AcOH}-\mathrm{AcOLi}$ & $12.5: 87.5$ & 5.4 & 3.35 \\
$2.0 \mathrm{M} \mathrm{AcOH}-\mathrm{AcOLi}$ & $58.5: 41.5$ & 4.4 & 3.04 \\
$2.0 \mathrm{M} \mathrm{AcOH}-\mathrm{AcOLi}$ & $95.0: 5.0$ & 3.3 & 0.586 \\
$5.0 \mathrm{M} \mathrm{AcOH}-\mathrm{AcOLi}$ & $12.5: 87.5$ & 5.4 & 3.76 \\
$0.1 \mathrm{M} \mathrm{AcOH}+1.0 \mathrm{M} \mathrm{Li}_{2} \mathrm{SO}_{4}$ & $5.0: 95.0$ & 4.2 & 6.87 \\
Phosphate buffered saline & - & 7.3 & - \\
Fetal bovine serum & - & 7.4 & -
\end{tabular}

de-intercalation of $\mathrm{Na}^{+}$with aqueous $\mathrm{Na}_{2} \mathrm{~S}_{2} \mathrm{O}_{8}$ and subsequent proton exchange in $1 \mathrm{M} \mathrm{HCl}$ leads to the layered $\mathrm{H}_{0.2} \mathrm{RuO}_{2} \cdot 0.5 \mathrm{H}_{2} \mathrm{O}$. The layered ruthenic acid was added to a tetrabutylammonium hydroxide (TBAOH) aqueous solution with the molar ratio of TBA ions to the exchangeable protons in $\mathrm{H}_{0.2} \mathrm{RuO}_{2} \cdot 0.5 \mathrm{H}_{2} \mathrm{O}$ adjusted to $\mathrm{TBA}^{+} / \mathrm{H}^{+}$ $=5$. The dispersion was vigorously shaken for 10 days to exfoliate the layered ruthenate into elementary $\mathrm{RuO}_{2}$ nanosheets. The resultant suspension was centrifugated at 2,000 rpm for $30 \mathrm{~min}$ to remove trace amounts of impurity Ru metal and non-exfoliated material.

Electrochemical measurements were carried out using a beakertype electrochemical cell composed of a Pt mesh counter electrode and a $\mathrm{Ag} / \mathrm{AgCl} / \mathrm{KCl}$ (sat.) reference electrode connected with a salt bridge. A Luggin capillary faced the working electrode at a distance of $2 \mathrm{~mm}$. Electrode potentials will be referred to the reversible hydrogen electrode (RHE) potential scale. The working electrodes for $\mathrm{RuO}_{2} \cdot n \mathrm{H}_{2} \mathrm{O}$ and anhydrous $\mathrm{RuO}_{2}$ was prepared by coating the active material on a glassy carbon surface $\left(\sim 200 \mu \mathrm{g} \mathrm{cm}^{-2}\right)$. A thin layer of Nafion ionomer was cast on the electrode as a proton conductive binder. Re-stacked $\mathrm{RuO}_{2}$ nanosheet electrodes were prepared by dropping a colloidal suspension onto a mirror-polished glassy carbon $\operatorname{rod}\left(\sim 20 \mu \mathrm{g} \mathrm{cm}^{-2}\right)$. The capacitance was calculated by averaging the anodic and cathodic charge. Cyclic voltammetry was conducted in $\mathrm{H}_{2} \mathrm{SO}_{4}, \mathrm{Li}_{2} \mathrm{SO}_{4}, \mathrm{AcOLi}$, and $\mathrm{AcOH}-\mathrm{AcOLi}$ at $60^{\circ} \mathrm{C}$ unless otherwise noted with the scan rate $2,5,20,50,200,500 \mathrm{mV} \mathrm{s}^{-1}$. Phosphate buffered saline and fetal bovine serum (Biowest, France) was used as-received. The electrolytes used in this study are summarized in Table I.

\section{Results and Discussion}

Impact of electrolyte on the pseudocapacitive properties of $\mathrm{RuO}_{2} \cdot n \mathrm{H}_{2} \mathrm{O}$. - Cyclic voltammograms of $\mathrm{RuO}_{2} \cdot n \mathrm{H}_{2} \mathrm{O}$ nanoparticles in $0.5 \mathrm{M} \mathrm{H}_{2} \mathrm{SO}_{4}, 1.0 \mathrm{M} \mathrm{Li}_{2} \mathrm{SO}_{4}, 2.0 \mathrm{M} \mathrm{AcOLi}$, and $2.0 \mathrm{M} \mathrm{AcOH}-$ AcOLi are shown in Fig. 1A. The voltammograms in $0.5 \mathrm{M} \mathrm{H}_{2} \mathrm{SO}_{4}$ are typical of sol-gel derived $\mathrm{RuO}_{2} \cdot n \mathrm{H}_{2} \mathrm{O}$ nanoparticles with a maximum capacitance of $720 \mathrm{~F} \mathrm{~g}^{-1}$ at $2 \mathrm{mV} \mathrm{s}^{-1}$, decreasing by $18 \%$ to $589 \mathrm{~F} \mathrm{~g}^{-1}$ at $500 \mathrm{mV} \mathrm{s}^{-1}$. A broad redox peak at $E_{1 / 2}=0.60 \mathrm{~V}$ vs RHE can be clearly distinguished.

The cyclic voltammograms in $1.0 \mathrm{M} \mathrm{Li}_{2} \mathrm{SO}_{4}$ are characterized by a rectangular background current (shown as shaded region in the figure), and a slow irreversible redox process above $0.8 \mathrm{~V}$ and below $0.6 \mathrm{~V}$ vs RHE on the anodic and cathode scans, respectively. The rectangular background current is superimposed for the other electrolytes assuming that the $C_{\mathrm{dl}}$ is the same regardless of electrolyte. Here we are disregarding the size of the (solvated) ions for sake of simplicity. The specific capacitance due to electrical double layer charging $\left(C_{\mathrm{dl}}\right)$ in $1.0 \mathrm{M} \mathrm{Li}_{2} \mathrm{SO}_{4}$ is estimated as $\sim 200 \mathrm{~F} \mathrm{~g}^{-1}$ from the scan rate independent region. This capacitance translates to an estimated surface area of $1,000 \mathrm{~m}^{2} \mathrm{~g}^{-1}$ or $1.0 \mathrm{~nm}$ particle size, taking the value of $20 \mu \mathrm{F}$ $\mathrm{cm}^{-2}$ as a probe value for area specific capacitance. This particle size is in good agreement with the local structure derived by EXFAS $^{24}$ and SAXS. ${ }^{25}$

The pseudocapacitance due to surface redox processes $\left(C_{\text {redox }}\right)$ is calculated by subtracting $C_{\mathrm{dl}}$ from the overall capacitance $C$ at the respective scan rates and is shown in Fig. 1B. The slow irreversible redox process above $0.8 \mathrm{~V}$ and below $0.6 \mathrm{~V}$ can be interpreted as the dissociative adsorption of water according to reaction $1 .{ }^{15,16}$

$$
\mathrm{Ru}_{2} \mathrm{O}_{3}+\mathrm{H}_{2} \mathrm{O} \rightleftharpoons 2 \mathrm{RuO}_{2}+2 \mathrm{e}^{-}+2 \mathrm{H}^{+}
$$

The behavior in $2.0 \mathrm{M}$ AcOLi is similar to $\mathrm{Li}_{2} \mathrm{SO}_{4}$ in many aspects. The $C_{\mathrm{dl}}$ values in AcOLi and $\mathrm{Li}_{2} \mathrm{SO}_{4}$ are both $\sim 200 \mathrm{~F} \mathrm{~g}^{-1}$. The redox peaks due to reaction 1 is observed at $E_{1 / 2}=0.70 \mathrm{~V}$, which is close
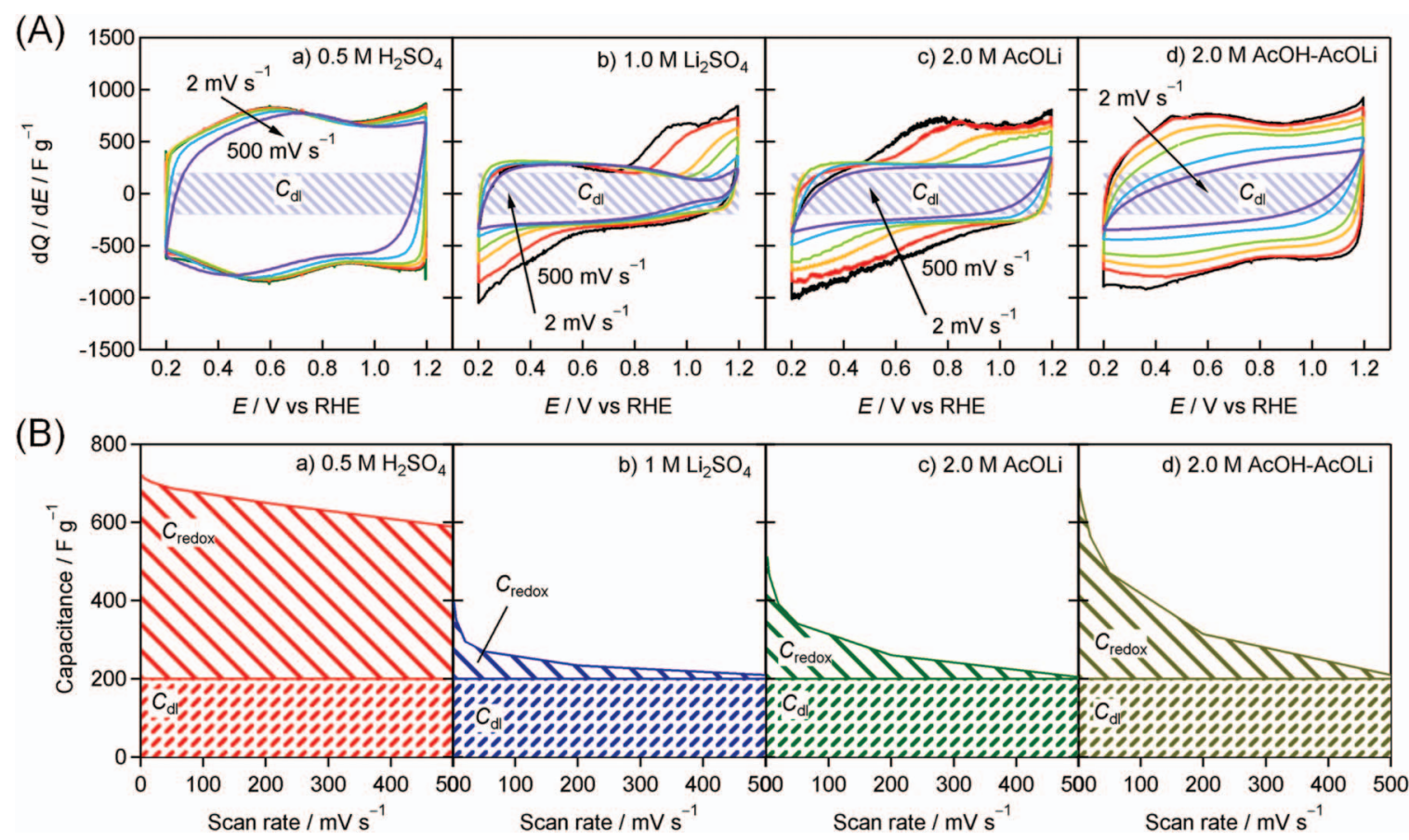

Figure 1. (A) Cyclic voltammograms of $\mathrm{RuO}_{2} \cdot n \mathrm{H}_{2} \mathrm{O}$ in a) $0.5 \mathrm{M} \mathrm{H}_{2} \mathrm{SO}_{4}$, b) $1.0 \mathrm{M} \mathrm{Li}_{2} \mathrm{SO}_{4}$, c) $2.0 \mathrm{M} \mathrm{AcOLi}$, and d) $2.0 \mathrm{M} \mathrm{AcOH}-\mathrm{AcOLi}$ at $60^{\circ} \mathrm{C}$ with $v=2$, $5,20,50,200$, and $500 \mathrm{mV} \mathrm{s}^{-1}$. (B) The overall capacitance deconvoluted into the electrical double layer capacitance $\left(C_{\mathrm{dl}}=200 \mathrm{~F} \mathrm{~g}^{-1}\right)$ and redox capacitance $\left(C_{\text {redox }}\right)$. 

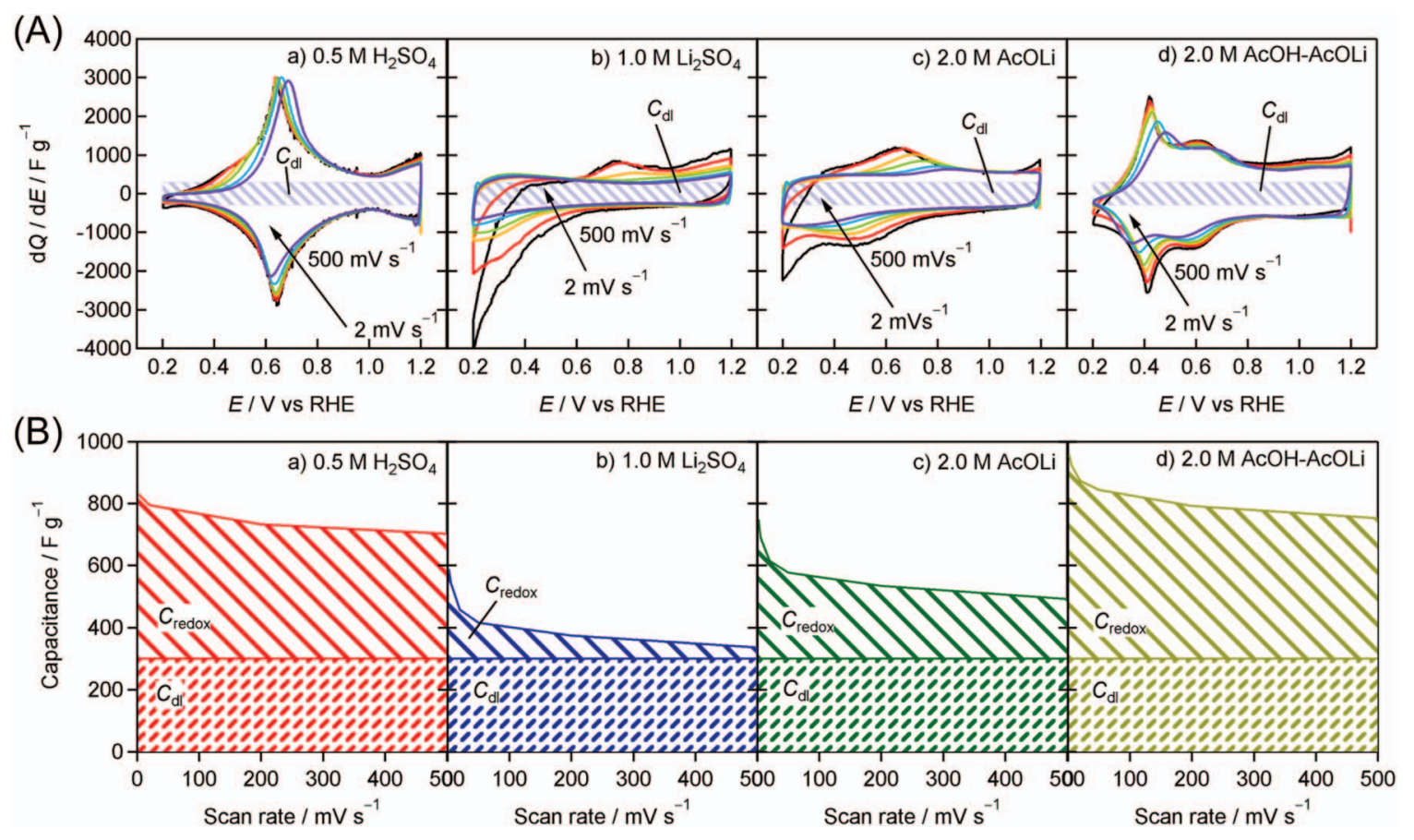

Figure 2. (A) Cyclic voltammograms of $\mathrm{RuO}_{2}$ nanosheets in a) $0.5 \mathrm{M} \mathrm{H}_{2} \mathrm{SO}_{4}$, b) $1.0 \mathrm{M} \mathrm{Li}_{2} \mathrm{SO}_{4}$, c) $2.0 \mathrm{M} \mathrm{AcOLi}$, and d) $2.0 \mathrm{M} \mathrm{AcOH}-\mathrm{AcOLi}$ at $60^{\circ} \mathrm{C}$ with $v=2,5,20,50,200$, and $500 \mathrm{mV} \mathrm{s}^{-1}$. (B) The overall capacitance deconvoluted into the electrical double layer capacitance $\left(C_{\mathrm{dl}}=300 \mathrm{~F} \mathrm{~g}^{-1}\right)$ and redox capacitance $\left(C_{\text {redox }}\right)$.

to the $\mathrm{Ru}^{4+} / \mathrm{Ru}^{3+}$ potential according to the Pourbaix diagram ${ }^{26}$ for this reaction. An obvious difference is the charge related to reaction 1; The charge is higher in $2.0 \mathrm{M}$ AcOLi. This difference may be due to specific adsorption of $\mathrm{SO}_{4}{ }^{2-}$ on the oxide surface, hindering the adsorption of water, and thus delaying reaction 1.

The behavior in $2.0 \mathrm{M} \mathrm{AcOH}-\mathrm{AcOLi}$ seems to be a combination of the behavior in $\mathrm{H}_{2} \mathrm{SO}_{4}$ and AcOLi depending on the scan rate. At slow scan rates the voltammograms are similar to that in $\mathrm{H}_{2} \mathrm{SO}_{4}$ and a capacitance of $687 \mathrm{~F} \mathrm{~g} \mathrm{~g}^{-1}$ at $2 \mathrm{mV} \mathrm{s}^{-1}$ is obtained. On the other hand, only electrical double layer charging occurs at fast scan rates in AcOLi, reducing the capacitance to $210 \mathrm{~F} \mathrm{~g}^{-1}$ at $500 \mathrm{mV} \mathrm{s}^{-1}$. This phenomenon (lack of pseudocapacitance at high scan rates) is due to the low proton concentration in $2.0 \mathrm{M}$ AcOH-AcOLi. Surface redox process related with hydrated protons will become diffusion limited at high scan rates. If we take the $C_{\mathrm{dl}}$ values of $\sim 200 \mathrm{~F} \mathrm{~g}^{-1}$ from AcOLi, $C_{\text {redox }}$ in $2.0 \mathrm{M} \mathrm{AcOH}-\mathrm{AcOLi}$ becomes extremely large $\left(487 \mathrm{~F} \mathrm{~g}^{-1}\right.$ or $64.8 \mathrm{kC} \mathrm{mol}^{-1}$ ). Dividing $64.8 \mathrm{kC} \mathrm{mol}^{-1}$ by the Faraday constant $96.5 \mathrm{kC} \mathrm{mol}^{-1}$ gives a 0.6 electron reaction for $C_{\text {redox }}$. Since not all of the $\mathrm{Ru}$ ions will be in the outer shell of the nanoparticle, this value seems to be a reasonable value for pseudocapacitance.

Using the $C_{\mathrm{dl}}$ values obtained in neutral electrolytes, we can calculate the $C_{\text {redox }}$ in $0.5 \mathrm{M} \mathrm{H}_{2} \mathrm{SO}_{4}$ as $400-500 \mathrm{~F} \mathrm{~g}^{-1}$. The $E_{1 / 2}=0.60 \mathrm{~V}$ vs $\mathrm{RHE}$ in $\mathrm{H}_{2} \mathrm{SO}_{4}$ is also attributed to reaction $1 .{ }^{16}$ Note that if we take differential capacitance that is mostly scan-rate independent in $\mathrm{H}_{2} \mathrm{SO}_{4}$ as the $C_{\mathrm{dl}}$ (which is often practiced in literature (see for example ref $[27,28])), C_{\mathrm{dl}}$ can be estimated as $500 \mathrm{~F} \mathrm{~g}^{-1}$. The probe value of $80 \mu \mathrm{F} \mathrm{cm}^{-2}$ is often used as a measure of the specific capacitance in $\mathrm{H}_{2} \mathrm{SO}_{4}$, which originates from the above mentioned treatment. The results and discussion shown here using various electrolytes suggests that this probe value contains both $C_{\mathrm{dl}}$ and $C_{\text {redox }}$ charge.

The pseudocapacitive behavior of anhydrous $\mathrm{RuO}_{2}$ nanoparticles in $0.5 \mathrm{M} \mathrm{H}_{2} \mathrm{SO}_{4}, 1.0 \mathrm{M} \mathrm{Li}_{2} \mathrm{SO}_{4}, 2.0 \mathrm{M} \mathrm{AcOLi}$, and $2.0 \mathrm{M} \mathrm{AcOH}$ AcOLi are qualitatively similar to $\mathrm{RuO}_{2} \cdot n \mathrm{H}_{2} \mathrm{O}$ (Fig. S1). The change in molarity of AcOH-AcOLi between 0.5 and 5.0 M does not affect the voltammograms significantly (Fig. S2). At the lowest concentration of $0.5 \mathrm{M}$, a peak at $E_{1 / 2}=0.41 \mathrm{~V}$ evolves at slow scan rate, which is attributable to the adsorption of $\mathrm{AcOH}$ (discussed in detail later).
Pseudocapacitive properties of $\mathrm{RuO}_{2}$ nanosheets in various electrolytes. - Cyclic voltammograms of $\mathrm{RuO}_{2}$ nanosheets in $0.5 \mathrm{M}$ $\mathrm{H}_{2} \mathrm{SO}_{4}, 1.0 \mathrm{M} \mathrm{Li}_{2} \mathrm{SO}_{4}, 2.0 \mathrm{M} \mathrm{AcOLi}$, and $2.0 \mathrm{M} \mathrm{AcOH}-\mathrm{AcOLi}$ are shown in Fig. 2A. The voltammograms in $0.5 \mathrm{M} \mathrm{H}_{2} \mathrm{SO}_{4}$ are quite different from sol-gel derived $\mathrm{RuO}_{2} \cdot n \mathrm{H}_{2} \mathrm{O}$ nanoparticles in that there is a distinctive large redox pair at $E_{1 / 2}=0.64 \mathrm{~V}$ vs. RHE. The capacitance at $2 \mathrm{mV} \mathrm{s}^{-1}$ is $831 \mathrm{~F} \mathrm{~g}^{-1}$ and decreases by $15 \%$ to $703 \mathrm{~F} \mathrm{~g}^{-1}$ at $500 \mathrm{mV} \mathrm{s}^{-1}$. Following the case for $\mathrm{RuO}_{2} \cdot n \mathrm{H}_{2} \mathrm{O}$ nanoparticles, the $C_{\mathrm{dl}}$ value can be deduced from the constant $\mathrm{d} Q / \mathrm{d} E$ background current taken in $\mathrm{Li}_{2} \mathrm{SO}_{4}$, which is $C_{\mathrm{dl}} \sim 300 \mathrm{~F} \mathrm{~g}^{-1}$. The deconvoluted $C_{\mathrm{dl}}$ and $C_{\text {redox }}$ contribution at the respective scan rates are given in Fig. 2B. Using the $C_{\mathrm{dl}}$ value and $20 \mu \mathrm{F} \mathrm{cm}^{-2}$, the electrochemically accessible surface area is estimated as $1,500 \mathrm{~m}^{2} \mathrm{~g}^{-1}$. This is much higher than the theoretical surface area of $\sim 400 \mathrm{~m}^{2} \mathrm{~g}^{-1}$ for a $\mathrm{RuO}_{2}$ nanosheet crystallite with thickness of $0.7 \mathrm{~nm}$. The estimated $C_{\mathrm{dl}} \sim 300 \mathrm{~F} \mathrm{~g}^{-1}$ most likely includes pseudocapacitance from fast surface redox processes. $C_{\text {redox }}$ due to reaction 1 is observed also for $\mathrm{RuO}_{2}$ nanosheets in $\mathrm{Li}_{2} \mathrm{SO}_{4}$ and $\mathrm{AcOLi}$, although the contribution is much smaller than for $\mathrm{RuO}_{2} \cdot n \mathrm{H}_{2} \mathrm{O}$ nanoparticles. The cathodic current below $0.6 \mathrm{~V}$ and corresponding oxidation current at $E=0.75 \mathrm{~V}$ in $\mathrm{Li}_{2} \mathrm{SO}_{4}$ and $\mathrm{AcOLi}$ (Fig. 2A(b) and (c)) may be due to hydrogen adsorption. ${ }^{28}$ The behavior of $\mathrm{RuO}_{2}$ nanosheets in $2.0 \mathrm{M} \mathrm{AcOH}-\mathrm{AcOLi}$ is characterized by two pairs of redox peaks at $E_{1 / 2}=0.41$ and $0.60 \mathrm{~V}$ vs RHE. The former pair is more scan rate dependent than the latter. The overall capacitance is $958 \mathrm{~F} \mathrm{~g}^{-1}$ at $2 \mathrm{mV} \mathrm{s}^{-1}$ and $752 \mathrm{~F} \mathrm{~g}^{-1}$ at $500 \mathrm{mV} \mathrm{s}^{-1}$. The $C_{\text {redox }}$ in $\mathrm{H}_{2} \mathrm{SO}_{4}$ and $\mathrm{AcOH}-\mathrm{AcOLi}$ represents 50 to $70 \%$ of the overall capacitance.

The distinctive redox peaks observed for $\mathrm{RuO}_{2}$ nanosheets changes drastically when the ionic strength of the AcOH-AcOLi buffer solution is changed while keeping a constant $\mathrm{pH}$ (Fig. S3) ${ }^{20}$ The redox pair at $E_{1 / 2}=0.41 \mathrm{~V}$ is strongly dependent on the ionic strength, broadening and decreasing in charge with decreasing $\mathrm{AcOH}-\mathrm{AcOLi}$ concentration. The $E_{1 / 2}=0.60 \mathrm{~V}$ peak is less dependent on the AcOHAcOLi concentration. These observations can be attributed to decreasing concentration of the active species. It is noted that at the highest concentration of $5.0 \mathrm{M} \mathrm{AcOH}-\mathrm{AcOLi}$, a remarkable capacitance of $1,038 \mathrm{~F} \mathrm{~g}^{-1}$ is obtained. ${ }^{20}$ 

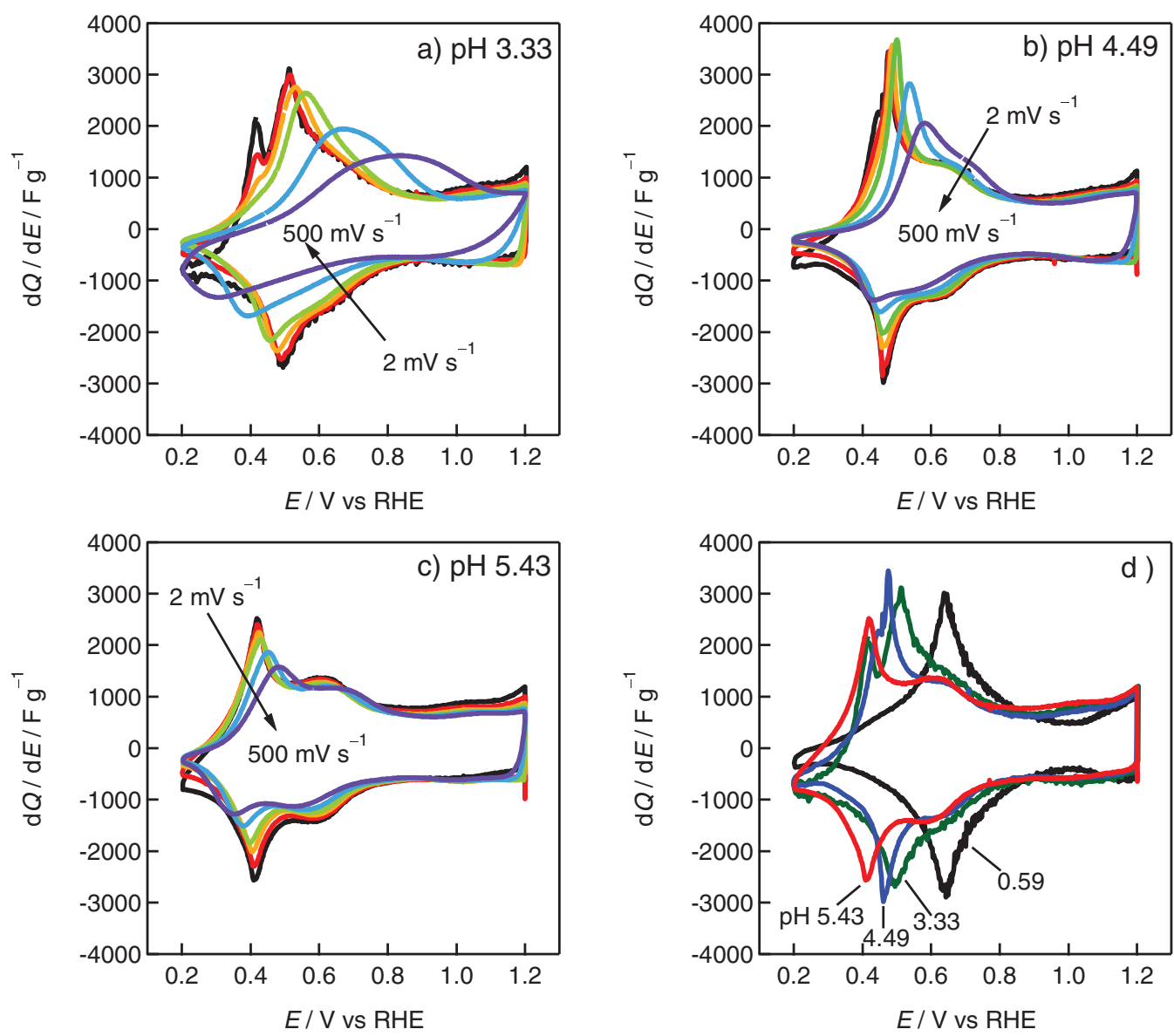

Figure 3. Cyclic voltammograms of $\mathrm{RuO}_{2}$ nanosheets at 2, 5, 20, 50, 200, $500 \mathrm{mV} \mathrm{s}^{-1}$ in $2.0 \mathrm{M} \mathrm{AcOH}-\mathrm{AcOLi}$ at pH of a) 3.33 , b) 4.49 , and c) 5.43 . d) $\mathrm{Cyclic}$ voltammograms of $\mathrm{RuO}_{2}$ nanosheet at $2 \mathrm{mV} \mathrm{s}^{-1}$ in $2.0 \mathrm{M} \mathrm{AcOH}-\mathrm{AcOLi}$ with various $\mathrm{pH}$ and $0.5 \mathrm{M} \mathrm{H}_{2} \mathrm{SO}_{4}$.

In order to gain further insight into the origin of the redox peaks, the $\mathrm{pH}$ of the buffer solution was controlled by changing the salt/supporting electrolyte volumetric ratio. As shown in Fig. 3, as the $\mathrm{pH}$ is lowered, the cyclic voltammograms become strongly scan rate dependent, which is due to the decrease in the conductivity of the buffer solutions. Figure $3 \mathrm{~d}$ compares the voltammograms at $2 \mathrm{mV}$ $\mathrm{s}^{-1}$. The $E_{1 / 2}=0.60 \mathrm{~V}$ vs RHE peak is independent of $\mathrm{pH}$ (note that in $\mathrm{H}_{2} \mathrm{SO}_{4}$, the $E_{1 / 2}=0.41$ and $0.60 \mathrm{~V}$ vs RHE peaks overlap). The $E_{1 / 2}=0.60 \mathrm{~V}$ vs RHE peak is attributed to reaction 1, similar to the case for $\mathrm{RuO}_{2} \cdot n \mathrm{H}_{2} \mathrm{O}$ nanoparticles. The $E_{1 / 2}=0.41 \mathrm{~V}$ vs RHE (at $\mathrm{pH}=5.43$ ) shifts to positive potentials as the $\mathrm{pH}$ is decreased. This peak shows a linear relation with $\mathrm{pH}$ (Fig. 4), suggesting that it is related to adsorption of protons or hydrated protons. Analysis of the slope shows that this is a 1.5 electron reaction, or 3 electrons per 2 reaction sites. This irregular behavior is consistent with previous studies on hydrous metal oxide films of $\mathrm{Ir}$ and $\mathrm{Ru} .^{29-31}$

Figure 5 shows comparative data of the change in $\mathrm{pH}$ for $\mathrm{RuO}_{2} \cdot n \mathrm{H}_{2} \mathrm{O}$ nanoparticles. The cyclic voltammograms for $\mathrm{H}_{2} \mathrm{SO}_{4}$ and $2.0 \mathrm{M}$ AcOH-AcOLi ( $\mathrm{pH}=5.36)$ completely overlap, suggesting an analogous charge storage mechanism. On the other hand, the electrochemical behavior in $2.0 \mathrm{M} \mathrm{AcOH}-\mathrm{AcOLi}$ with $\mathrm{pH}=4.44$ and 3.42 are quite different. For $\mathrm{pH}=3.42$, the electrical double layer capacitance is completely lost. We attribute this peculiarity to adsorption of molecular $\mathrm{AcOH}$ (not $\mathrm{AcO}^{-}$) on the surface of $\mathrm{RuO}_{2}$, blocking the electrical double layer formation. As the $\mathrm{pH}$ is lowered, the relative content of $\mathrm{AcOH}$ increases (Table I). In the case of $2.0 \mathrm{M} \mathrm{AcOH}-$ AcOLi ( $\mathrm{pH}=5.36$ ), the adsorption of $\mathrm{AcOH}$ is not evident since the concentration of $\mathrm{AcOH}$ is much smaller than at $\mathrm{pH}=4.44$ and 3.42. A similar phenomena was observed for adsorption of $\mathrm{CH}_{3} \mathrm{OH}$ in $\mathrm{H}_{2} \mathrm{SO}_{4}$, where $\mathrm{CH}_{3} \mathrm{OH}$ is adsorbed on $\mathrm{RuO}_{2} \cdot n \mathrm{H}_{2} \mathrm{O}$ nanoparticles. ${ }^{23}$
The reason for the absence of $\mathrm{AcOH}$ adsorption on $\mathrm{RuO}_{2}$ nanosheets cannot be identified at this point, but it should be noted that $\mathrm{CH}_{3} \mathrm{OH}$ also does not adsorb on $\mathrm{RuO}_{2}$ nanosheets. ${ }^{23}$

A weak acid in a supporting electrolyte.- Figure 6 shows cyclic voltammograms when a small amount of $\mathrm{AcOH}$ was added to $\mathrm{Li}_{2} \mathrm{SO}_{4}$ $\left(0.1 \mathrm{M} \mathrm{AcOH}+1.0 \mathrm{M} \mathrm{Li}_{2} \mathrm{SO}_{4}, \mathrm{pH}=4.16\right)$. At slow scan rates

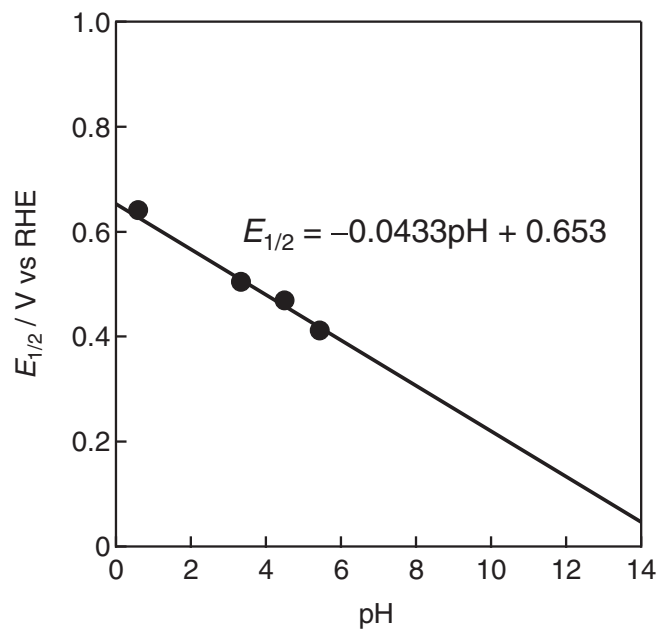

Figure 4. Plots of $E_{1 / 2}$ of redox peaks for $\mathrm{RuO}_{2}$ nanosheets in $2.0 \mathrm{M} \mathrm{AcOH}$ AcOLi and $0.5 \mathrm{M} \mathrm{H}_{2} \mathrm{SO}_{4}$ as a function of the $\mathrm{pH}$. 

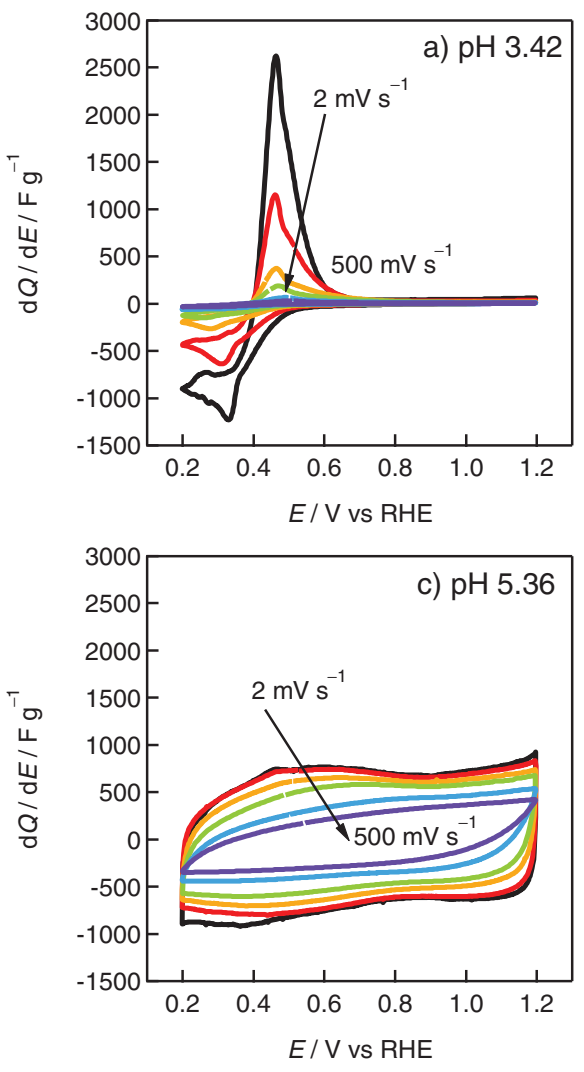
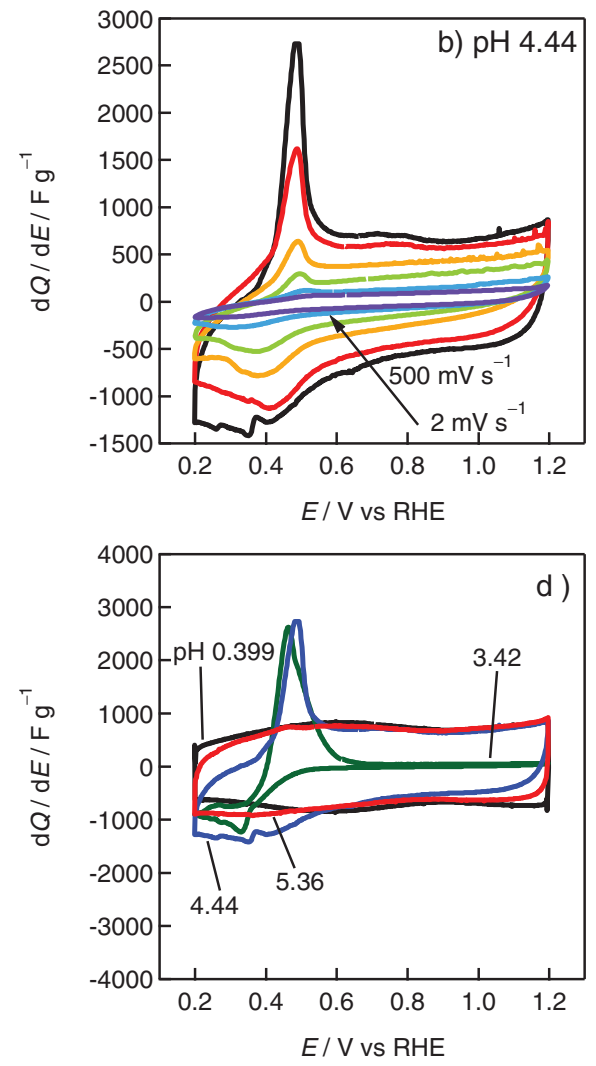

Figure 5. Cyclic voltammograms of $\mathrm{RuO}_{2} \cdot n \mathrm{H}_{2} \mathrm{O}$ at $2,5,20,50,200,500 \mathrm{mV}$ $\mathrm{s}^{-1}$ in $2.0 \mathrm{M} \mathrm{AcOH}-\mathrm{AcOLi}$ at $\mathrm{pH}$ of a) 3.42 , b) 4.44 , and c) 5.36. d) Cyclic voltammograms of $\mathrm{RuO}_{2}$ nanosheets at $2 \mathrm{mV} \mathrm{s}{ }^{-1}$ in $2.0 \mathrm{M}$ $\mathrm{AcOH}-\mathrm{AcOLi}$ with various $\mathrm{pH}$ and $0.5 \mathrm{M}$ $\mathrm{H}_{2} \mathrm{SO}_{4}$.

(A)

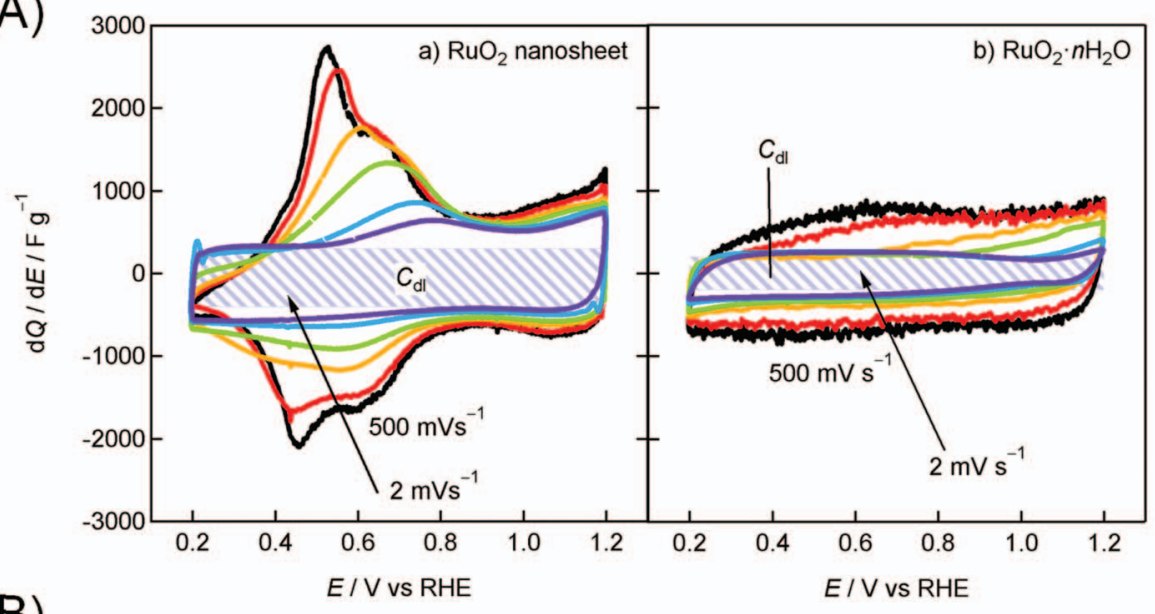

(B)

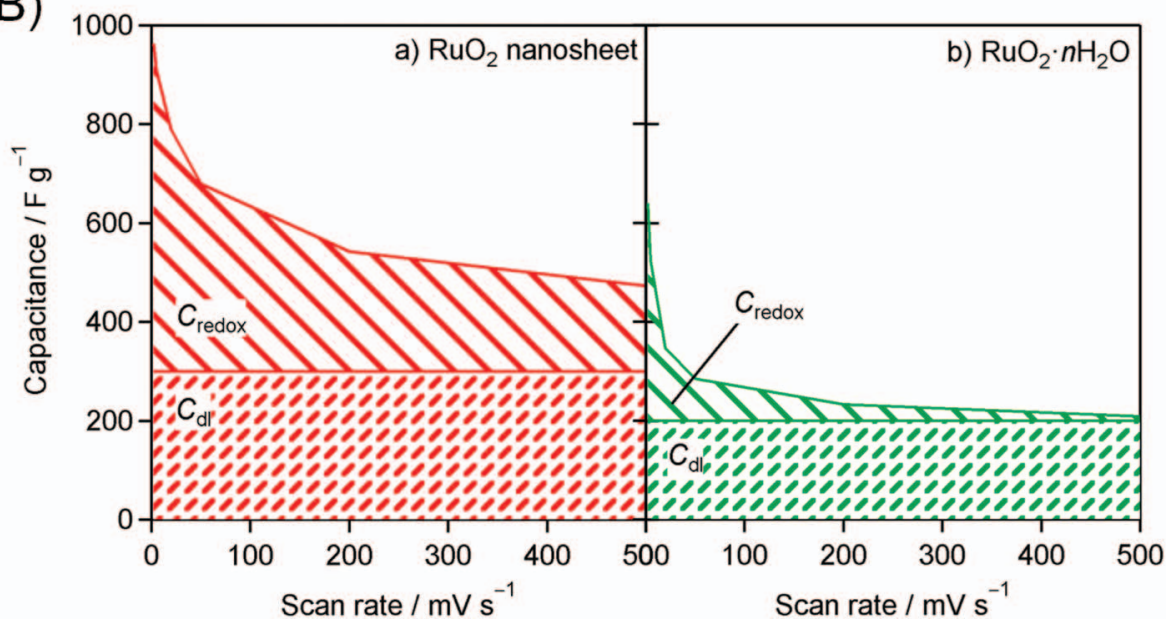

Figure 6. (A) Cyclic voltammograms and (B) deconvoluted of specific capacitance for a) $\mathrm{RuO}_{2}$ nanosheets and b) $\mathrm{RuO}_{2} \cdot n \mathrm{H}_{2} \mathrm{O}$ in $0.1 \mathrm{M} \mathrm{AcOH}$ $1.0 \mathrm{M} \mathrm{Li}_{2} \mathrm{SO}_{4}$ (pH 4.16). 


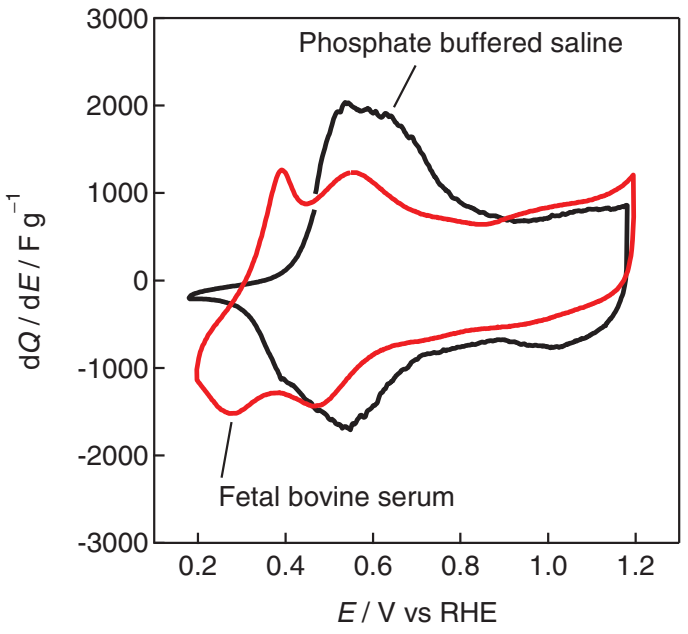

Figure 7. Cyclic voltammograms of $\mathrm{RuO}_{2}$ nanosheets at $2 \mathrm{mV} \mathrm{s}^{-1}$ in phosphate buffered saline and fetal bovine serum at $25^{\circ} \mathrm{C}$.

the cyclic voltammograms for $\mathrm{RuO}_{2} \cdot n \mathrm{H}_{2} \mathrm{O}$ nanoparticles and $\mathrm{RuO}_{2}$ nanosheets both resemble the behavior in AcOH-AcOLi buffered solutions. The capacitance at $2 \mathrm{mV} \mathrm{s}^{-1}$ is 639 and $962 \mathrm{~F} \mathrm{~g}^{-1}$ for $\mathrm{RuO}_{2} \cdot n \mathrm{H}_{2} \mathrm{O}$ nanoparticles and $\mathrm{RuO}_{2}$ nanosheets, respectively. On the other hand, at fast scan rate, the voltammograms are similar to those in $\mathrm{Li}_{2} \mathrm{SO}_{4}$, since the concentration of $\mathrm{AcOH}$ is very small. This clearly shows that protons contribute to the pseudocapacitive behavior of $\mathrm{RuO}_{2}$-based nanostructures. Thus, an electrolyte composed of a weak acid and a supporting electrolyte can also be used as an electrolyte for pseudocapacitors. Buffered solutions have the advantage of $\mathrm{pH}$ control, ionic strength, and biocompatibility, compared to a weak acid in supporting electrolyte. However, the finding that such a simple mixture can be used as an electrolyte for pseudocapacitors paves the way to a massive combination of new electrolytes to explore.

Bio-supercapacitor based on phosphate buffered saline and fetal bovine serum. - Besides the benefit of control in $\mathrm{pH}$ and ionic strength, buffered solutions have the advantage of biocompatibility, as many buffers exist in nature (sea water, blood, internal cell fluids, cells and tissues). Here we demonstrate the use of phosphate buffered saline and fetal bovine serum as bioelectrolytes for supercapacitors applicable to safe and bio-compatible implantable power sources. Figure 7 shows the cyclic voltammograms of $\mathrm{RuO}_{2}$ nanosheets in phosphate buffered saline and fetal bovine serum at $25^{\circ} \mathrm{C}$. The redox behavior and capacitance are similar to the AcOH-AcOLi system. The specific capacitance at $2 \mathrm{mV} \mathrm{s}^{-1}$ in phosphate buffered saline was $837 \mathrm{~F} \mathrm{~g}^{-1}$, and $772 \mathrm{~F} \mathrm{~g}^{-1}$ in fetal bovine serum. These values are at least twice as large as those of MWCNTs/PANI composite in physiological electrolyte and human serum. ${ }^{32}$ The results potentially show that the combination of pseudocapacitive oxide electrodes and bioelectrolytes can afford exceptionally high energy density.

\section{Conclusions}

The electrochemical charge storage in buffered solutions using poorly-crystalline hydrous $\mathrm{RuO}_{2}$ nanoparticles and well-crystalline $\mathrm{RuO}_{2}$ nanosheets as electrode materials was studied. Capacitance comparable to or higher than $\mathrm{H}_{2} \mathrm{SO}_{4}$ were obtained in acetic acidlithium acetate (AcOH-AcOLi) buffered solutions, depending on the ionic strength and $\mathrm{pH}$. At constant $\mathrm{pH}, \mathrm{AcOH}-\mathrm{AcOLi}$ with higher ionic strength (molarity) lead to higher capacitance, owing to the presence of higher concentration of the adsorbant in the electrolyte. When the $\mathrm{pH}$ is varied by changing the volume ratio of $\mathrm{AcOH}-\mathrm{AcOLi}$, the pseudocapacitive behavior deteriorated with decreasing $\mathrm{pH}$. This phenomenon is discussed based on the decrease in the conductivity of the electrolyte. The highest capacitance of $1,038 \mathrm{~F} \mathrm{~g}^{-1}$ was obtained in a
$5 \mathrm{M} \mathrm{AcOH}-\mathrm{AcOLi}(\mathrm{pH}=5.4)$ with $\mathrm{RuO}_{2}$ nanosheet electrodes. $\mathrm{RuO}_{2}$ nanosheets afforded 20 to $50 \%$ higher capacitance than $\mathrm{RuO}_{2} \cdot n \mathrm{H}_{2} \mathrm{O}$ in all of the electrolytes studied $\left(\mathrm{H}_{2} \mathrm{SO}_{4}, \mathrm{Li}_{2} \mathrm{SO}_{4}, \mathrm{AcOLi}, \mathrm{AcOH}-\right.$ $\mathrm{AcOLi}, \mathrm{AcOH}-\mathrm{Li}_{2} \mathrm{SO}_{4}$ ). The lower capacitance of $\mathrm{RuO}_{2} \cdot n \mathrm{H}_{2} \mathrm{O}$ in $\mathrm{AcOH}-\mathrm{AcOLi}$ is due to the adsorption of $\mathrm{AcOH}$ molecules, which hinders the formation of the electrical double layer. Moreover, outstanding performance was obtained in phosphate buffered saline $\left(837 \mathrm{~F} \mathrm{~g}^{-1}\right)$ and fetal bovine serum $\left(772 \mathrm{~F} \mathrm{~g}^{-1}\right)$ with $\mathrm{RuO}_{2}$ nanosheet electrodes. The results presented here demonstrate the effective use of bioelectrolytes for pseudocapacitors applicable to environmentally begin, safe and bio-compatible implantable power sources.

\section{Acknowledgments}

This work was supported in part by the Advanced Low Carbon Technology Research and Development Program (ALCA) of the Japan Science and Technology Agency (JST) and Chubu Electric Power Co., Inc. W.S. wishes to thank Profs. Akira Teramoto and Koji Abe of Shinshu University for fruitful discussion on the bioelectrolytes. This manuscript is dedicated to the memory of Professor Koji Abe, an excellent researcher and a humble and modest colleague, who passed away suddenly on 18 November, 2014, during the course of the preparation of this manuscript.

\section{References}

1. B. Conway, Electrochemical supercapacitors: scientific fundamentals and technological applications, Kluwer Academic/Plenum Publishers, New York, USA, (1999).

2. V. Augustyn, P. Simon, and B. Dunn, Energy Environ. Sci., 7, 1597 (2014).

3. V. Augustyn, J. Come, M. a Lowe, J. W. Kim, P.-L. Taberna, S. H. Tolbert, H. D. Abruña, P. Simon, and B. Dunn, Nat. Mater., 12, 518 (2013).

4. M. Egashira, T. Uno, N. Yoshimoto, and M. Morita, Electrochemistry, 75, 595 (2007).

5. S. Makino, Y. Takasu, and W. Sugimoto, Chem. Lett., 39, 544 (2010).

6. L. Mayrand-Provencher, S. Lin, D. Lazzerini, and D. Rochefort, J. Power Sources, 195, 5114 (2010).

7. D. Rochefort and A.-L. Pont, Electrochem. Commun., 8, 1539 (2006).

8. K.-H. Chang, C.-C. Hu, C.-M. Huang, Y.-L. Liu, and C.-I. Chang, J. Power Sources, 196, 2387 (2011).

9. H. Y. Lee and J. B. Goodenough, J. Solid State Chem., 148, 81 (1999).

10. H. Y. Lee, V. Manivannan, and J. B. Goodenough, Comptes Rendus l'Académie des Sci. - Ser. IIC - Chem., 2, 565 (1999).

11. H. Y. Lee and J. B. Goodenough, J. Solid State Chem., 144, 220 (1999).

12. J. W. Long, D. Bélanger, T. Brousse, W. Sugimoto, M. B. Sassin, and O. Crosnier, MRS Bull., 36, 513 (2011).

13. Z. Chang, Y. Yang, M. Li, X. Wang, and Y. Wu, J. Mater. Chem. A, 2, 10739 (2014).

14. S. Wen, J. Lee, I. Yeo, J. Park, and S. Mho, Electrochim. Acta, 50, 849 (2004).

15. S. Sopčić, Z. Mandić, G. Inzelt, M. K. Roković, and E. Meštrović, J. Power Sources, 196, 4849 (2011).

16. S. Sopčić, M. K. Roković, Z. Mandić, A. Róka, and G. Inzelt, Electrochim. Acta, 56, 3543 (2011).

17. M. Tomkiewicz, Y. S. Huang, F. H. Pollak, and J. E. Soc, J. Electrochem. Soc., 130, 1514 (1983)

18. W. Shimizu, S. Makino, K. Takahashi, N. Imanishi, and W. Sugimoto, J. Power Sources, 241, 572 (2013)

19. S. Makino, Y. Shinohara, T. Ban, W. Shimizu, K. Takahashi, N. Imanishi, and W. Sugimoto, RSC Adv., 2, 12144 (2012).

20. S. Makino, T. Ban, and W. Sugimoto, Electrochemistry, 81, 795 (2013)

21. J. P. Zheng and T. R. Jow, J. Electrochem. Soc., 142, L6 (1995).

22. J. P. Zheng, P. J. Cygan, and T. R. Jow, J. Electrochem. Soc., 142, 2699 (1995).

23. K. Fukuda, T. Saida, J. Sato, M. Yonezawa, Y. Takasu, and W. Sugimoto, Inorg. Chem., 49, 4391 (2010).

24. D. A. McKeown, P. L. Hagans, L. P. L. Carette, A. E. Russell, K. E. Swider, and D. R. Rolison, J. Phys. Chem. B, 103, 4825 (1999).

25. N. Yoshida, Y. Yamada, S. Nishimura, Y. Oba, M. Ohnuma, and A. Yamada, J. Phys. Chem. C, 117, 12003 (2013).

26. M. Pourbaix, Atlas of Electrochemical Equilibria in Aqueous Solutions, 2nd ed., National Association of Corrosion Engineers, Houston, Tex, (1974).

27. W. Sugimoto, K. Yokoshima, Y. Murakami, and Y. Takasu, Electrochim. Acta, 52 , 1742 (2006)

28. W. Sugimoto, T. Kizaki, K. Yokoshima, Y. Murakami, and Y. Takasu, Electrochim. Acta, 49, 313 (2004)

29. L. D. Burke and O. J. Murphy, J. Electroanal. Chem. Interfacial Electrochem., 109, 199 (1980).

30. L. D. Burke, M. E. Lyons, E. J. M. O'Sullivan, and D. P. Whelan, J. Electroanal. Chem. Interfacial Electrochem., 122, 403 (1981).

31. L. D. Burke and J. F. Healy, J. Electroanal. Chem. Interfacial Electrochem., 124, 327 (1981).

32. M. Ammam and J. Fransaer, Chem. Commun., 48, 2036 (2012). 